
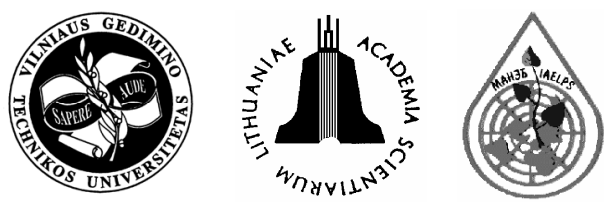

\title{
EFFECT OF EASILY BIODEGRADABLE AMENDMENTS ON HEAVY METAL SOLUBILIZATION AND ACCUMULATION IN TECHNICAL CROPS - A FIELD TRIAL
}

\author{
Stefan Shilev ${ }^{1}$, Mladen Naydenov ${ }^{1}$, Nurettin Tahsin ${ }^{2}$, Enrique D. Sancho $^{3}$, Manuel Benlloch ${ }^{4}$, \\ Ventsislava Vancheva ${ }^{1}$, Krasimira Sapundjieva ${ }^{1}$, Jordanka Kuzmanova ${ }^{1}$ \\ ${ }^{1}$ Dept of Microbiology and Environmental Biotechnologies, ${ }^{2}$ Dept of Plant Production, Agricultural \\ University-Plovdiv, 12, Mendeleev St, 4000-Plovdiv, Bulgaria. E-mail: stefan.shilev@au-plovdiv.bg \\ ${ }^{3}$ Dept of Microbiology, Build. C-6, ${ }^{4}$ Dept of Agronomy, Build. C-4, Campus Rabanales, \\ University of Córdoba, 14071-Córdoba, Spain. E-mail: edsancho@uco.es
}

Submitted 15 May 2007; accepted 1 Oct. 2007

\begin{abstract}
Heavy-metal soil pollution is a common environmental problem all over the world. In the induced phytoextraction process plants can transport and translocate to their above-ground tissues significant concentration of contaminants. Since some heavy metals are mostly presented in non-soluble state, the application of chelating agents is needed. In this study we introduced into the rhizosphere of maize (var. Kneja 530) and sunflower (var. Favorit) plants 1 and $5 \mathrm{mmol}^{-1}$ of EDDS and NTA, and $5 \mathrm{~g} \mathrm{~kg}^{-1}$ of nutrients to enhance the accumulated concentrations of cadmium, lead and zinc. The fraction of $\mathrm{CaCl}_{2}$-extractable metals increased incrementing the concentration of chelates. This was clearly pronounced for all the metals in the treatments with NTA and for Pb in those with EDDS. Generally, under all the experimental conditions the accumulated heavy-metal concentrations were found to be significantly higher than in the control. Thus, in the case of higher concentration of NTA and EDDS, the accumulated Cd in the leaves of sunflower was found to be threefold higher. The highest accumulation of $\mathrm{Pb}$ in the leaves of maize was observed when nutrients were added $\left(62 \mathrm{mg} \mathrm{kg}^{-1}\right)$. On the other hand, negative effects of the used chelating agents on soil bacteria and fungi at plant harvest were not observed. Moreover, when nutrients were added, the number of studied microorganisms significantly increased.
\end{abstract}

Keywords: heavy metals, phytoextraction, maize, sunflower, EDDS, NTA, field trial, rhizosphere microorganisms.

\section{Introduction}

Heavy-metal contamination of the soil is the main environmental problem in many countries. Heavy metals are basically characterized by their toxicity, persistence and difficulty to be removed. Some of them participate in a number of biochemical reactions in living beings [1], rising the attention regarding the toxic effects upon them and particularly upon the plants. An important toxicity mechanism of heavy metals is their capability to bind strongly the oxygen, nitrogen and sulfur atoms in plant cells, thus inactivate key enzymes binding the cisteine [2]. In other cases the enzyme inactivation occurs through substitution of one metal ion with another one in the molecule. Cations with the second valence could substitute the $\mathrm{Mg}^{2+}$ in the structure of some enzymes leading to the loss of activity [3]. The substitution of $\mathrm{Ca}^{2+}$ with $\mathrm{Cd}^{2+}$ results in inhibition of phosphoesterase cell activity [4].

Phytoremediation is a very promising technology for recuperation of contaminated sites. In this sense, induced phytoextraction, as a part of phytoremediation technologies, uses high biomass-producing plants, tolerant to metals, which extract within their roots and translocate to the above-ground parts significant quantities of the soil contaminant [5], decreasing the soil concentration.
Some agricultural crops possess high tolerance to growth in soils containing heavy metals, but do not accumulate their sufficient quantities, also because in many cases the metal concentration in soil solution is quite low. Heavy metals, as $\mathrm{Zn}$ and $\mathrm{Cd}$, are presented mainly in soluble form, while others, as $\mathrm{Pb}$, are less available because they occur basically in insoluble form [6]. Although, plants excrete from 10 to $20 \%$ of their photosynthetic products as root exudates and thus enhance the rhizosphere microbial activity and acidity, an increment of concentration of soluble metals into the soil solution could be reached using chelating amendments [7]. Blaylock et al., 1997 [8], communicated [8] that the application of EDTA (ethylene-diamine-tetraacetate) in concentration of $2 \mathrm{~g} \mathrm{~kg}^{-1}$ of soil leads to accumulation of $1.5 \% \mathrm{~Pb}$ in the shoots of Indian mustard (Brassica juncea) and approximately $1 \%$ in maize and pea. Other chelates, such as citric acid, DTPA (diethylene-triaminepentaacetate), NTA (nitrilo-triacetate), EDDS (ethylenediamine-disuccinate) also have been studied for their capacity to mobilize metals and thus enhance the accumulation [9, 10]. Easily biodegradable chelating agents are used to enhance metal solubility, absorption and translocation to the above-ground parts of plants. Because some of the chelating agents with wide application for 
mobilization of soil metals are slowly- or nonbiodegradable, raise the necessity to substitute these substances with other, biodegradable ones. EDTA is persistent in natural habitats, although according to some sources, EDTA is recalcitrant to biodegradation in soil $[11,12]$. Therefore, many investigators suggest that it is an unsuitable chelate and stake on the use of easily biodegradable ones, such as NTA or [S,S]-EDDS, in chemically-assisted phytoextraction of heavy metal-contaminated soil [13-15]. These chelates are easily biodegradable, strongly increasing metal concentration in soil solution and, in the case of EDDS, are frequently used in agriculture to provide plants with essential macroelements. In the last years several studies were made on the use of EDDS and NTA in chelate-enhanced phytoremediation of $\mathrm{Pb}, \mathrm{Cd}, \mathrm{Zn}$ and $\mathrm{Cu}$ in soil $[16,17,14]$. Luo et al. [13] found that the application of $5 \mathrm{mmol} \mathrm{kg}^{-1}$ of soil EDDS in the rhizosphere of maize was less effective that the same concentration of EDTA regarding phytoextraction of $\mathrm{Pb}$ in pot experiments. In addition, both chelates significantly increased the shoot to root ratio for $\mathrm{Pb}$, $\mathrm{Cd}, \mathrm{Zn}$ and $\mathrm{Cu}$. In other studies the addition of 10 and $20 \mathrm{mmol} \mathrm{kg}^{-1}$ of soil NTA lead to increment of Cd uptake in shoots two- and three-fold, respectively $[18,19]$.

Enhancing metal accumulation in high-yielding crop plants without diminishing their yield is fundamental to successful phytoextraction [8]. The inoculation with PGPR may facilitate plant growth and thus increase phytoremediation efficiency, although it did not greatly influence metal concentrations in plant tissues, but achieved a much larger above-ground biomass harvest, thus resulting in a much higher metal removal [20]. Moreover, autochthonous microbial species in contaminated soil could present significant tolerance to metals [21]. Microbial inoculation had a different influence on the speciation of metals in the soil and consequently altered the bioavailability of metals. On the other hand, the rhizosphere microorganisms can participate actively in solubilization of metals releasing different compounds, degrading soil organic matter and thus decreasing soil $\mathrm{pH}$. In this way, providing nutrients with different availability to these microorganisms could support soil metal solubilization and uptake by plants.

The aim of this study was to evaluate the possibilities for induced phytoextraction of cadmium, lead and zinc from contaminated soils using maize and sunflower plants and rhizosphere inoculation of easily-biodegradable chelating agents and nutrients.

\section{Materials and methods}

The experiments were carried out during 2006 in a contaminated area (arable land with Ca-reach soil) situated at $10 \mathrm{~km}$ to the south of the city of Plovdiv (South Bulgaria). Formerly, the area had been contaminated with $\mathrm{Pb}, \mathrm{Cd}$ and $\mathrm{Zn}$ by a non-ferrous metal factory.

After the grass coverage removal, the surface soil $(0-20 \mathrm{~cm})$ was collected, air-dried, sieved through a 2-mm sieve and prepared for analysis. The soil characteristics are is presented in Table 1.
Table 1. Physical and chemical characteristics of the contaminated soil (the results are the mean of three replicates)

\begin{tabular}{lc}
\hline Parameter & Values \\
\hline Clay $(\%)$ & 29.2 \\
Humus (\%) & 1.35 \\
$\mathrm{CaCO}_{3}(\%)$ & 7.1 \\
$\mathrm{pH}\left(\mathrm{H}_{2} \mathrm{O}\right)$ & 7.45 \\
$\mathrm{Mineral} \mathrm{N}\left(\mathrm{mg} \mathrm{kg}^{-1}\right)$ & 6.8 \\
$\mathrm{P}_{2} \mathrm{O}_{5}\left(\mathrm{mg} \mathrm{kg}^{-1}\right)$ & 87.5 \\
$\mathrm{~K}_{2} \mathrm{O}\left(\mathrm{g} \mathrm{kg}^{-1}\right)$ & 0.5 \\
$\mathrm{~Pb}\left(\mathrm{mg} \mathrm{kg}^{-1}\right)$ & 1020 \\
$\mathrm{Cd}\left(\mathrm{mg} \mathrm{kg}^{-1}\right)$ & 25.7 \\
$\mathrm{Cu}\left(\mathrm{mg} \mathrm{kg}^{-1}\right)$ & 137 \\
$\mathrm{Zn}\left(\mathrm{mg} \mathrm{kg}^{-1}\right)$ & 1890 \\
\hline
\end{tabular}

Seeds of two different crops [sunflower (Helianthus annuus L. var. Favorit) and maize (Zea mays L. var. Kneja 530)] were sown in the beginning of April in field plots of $20 \mathrm{~m}^{2}$ surface per plant in three replicates. Two weeks after the plant rising they were reduced leaving one plant each $30 \mathrm{~cm}$ and $70 \mathrm{~cm}$ between the rows. The nutrients (yeast extract as end-product, maize extract, starch) in concentration of $5 \mathrm{~g} \mathrm{l}^{-1}$ and biodegradable chelates in concentration of 1 and $5 \mathrm{mmol} \mathrm{l}^{-1}$ (NTA-1, NTA5, EDDS-1, EDDS-5) were added to the plant rhizosphere as water solutions, fourteen weeks after sowing. Ten days later the plant height was measured, and plant and soil samples were taken for analysis. During the vegetation all standard agricultural practices were applied.

Soil rhizosphere samples for analyses of heavy metal content and viable bacteria and filamentous fungi were taken at harvest. The analyses of total and $\mathrm{CaCl}_{2}$-soluble soil metal content were made as described by Karstensen et al., 1998 [22] and Maiz et al., 1997 [23]. The plant samples were first tap-water washed, oven-dried, weighed, milled and their portion was mixed with $\mathrm{HNO}_{3}$ and $\mathrm{H}_{2} \mathrm{O}_{2}$ and autoclave-digested [24]. All the samples were analyzed using Perkin Elmer AAS of the Department of Agronomy in the University of Córdoba. The estimation of colony-forming units $(c f u)$ of bacteria and fungi was made using plate dilution technique and inoculating on Nutrient agar and Czapek agar media.

This study was carried out in cooperation between the Agricultural University of Plovdiv (Bulgaria) and Depts of Microbiology and Agronomy in the University of Córdoba (Spain).

\section{Results}

Generally, the total soil metal content before the experiment was found to be higher than the maximum permissible limits established according to the Bulgarian law (Cd, $2.5 \mathrm{mg} \mathrm{kg}^{-1} ; \mathrm{Pb} 80 \mathrm{mg} \mathrm{kg}{ }^{-1} ; \mathrm{Zn}, 340 \mathrm{mg} \mathrm{kg}^{-1}$ ), while at harvest these values varied in certain ranges, depending on the treatment (Table 2). Lower total content for all the studied heavy metals was observed in the treatment with addition of nutrients. The fraction of $\mathrm{CaCl}_{2}$-extractable metals (expressed as percentage of the total content) increased incrementing the concentration of chelates. This was clearly pronounced for all the metals in the treatment 
Table 2. Total and $\mathrm{CaCl}_{2}$-extractable $\mathrm{Cd}, \mathrm{Pb}$ and $\mathrm{Zn}\left(\mathrm{mg} \mathrm{kg}^{-1}\right)$ after maize harvest. The results are presented as the mean and standard errors $(n=3)$

\begin{tabular}{|c|c|c|c|c|c|c|c|c|c|}
\hline \multirow{2}{*}{ Treatments } & \multicolumn{3}{|c|}{ Cd } & \multicolumn{3}{|c|}{$\mathbf{P b}$} & \multicolumn{3}{|c|}{ Zn } \\
\hline & total & $\mathrm{CaCl}_{2}$-extr. & $\%$ & total & $\mathrm{CaCl}_{2}$-extr. & $\%$ & total & $\mathrm{CaCl}_{2}$-extr. & $\%$ \\
\hline Control & $30 \pm 1.1$ & $0.63 \pm 0.18$ & 2.11 & $1023 \pm 49$ & $5.9 \pm 0.6$ & 0.58 & $1413 \pm 29$ & $0.3 \pm 0.1$ & 0.02 \\
\hline NTA-1 & $32.6 \pm 1.3$ & $0.87 \pm 0.18$ & 2.65 & $1012 \pm 56$ & $7 \pm 0.9$ & 0.69 & $1466 \pm 17.6$ & $5.4 \pm 1.3$ & 0.37 \\
\hline NTA-5 & $30 \pm 2.3$ & $1.03 \pm 0.2$ & 3.44 & $928 \pm 71.7$ & $6.9 \pm 1.1$ & 0.74 & $1406 \pm 104$ & $7 \pm 2.4$ & 0.5 \\
\hline EDDS-1 & $34 \pm 3.1$ & $0.97 \pm 0.23$ & 2.84 & $931 \pm 46.3$ & $3.6 \pm 0.4$ & 0.38 & $1513 \pm 65.6$ & $9.5 \pm 2.5$ & 0.63 \\
\hline EDDS-5 & $28.6 \pm 0.7$ & $0.47 \pm 0.07$ & 1.63 & $1058 \pm 24$ & $6.35 \pm 1$ & 0.6 & $1493 \pm 37$ & $8.2 \pm 1$ & 0.55 \\
\hline Nutrients & $27.3 \pm 1.7$ & $1.1 \pm 0.06$ & 4.02 & $926 \pm 76.9$ & $6.6 \pm 0.2$ & 0.71 & $1400 \pm 64.3$ & $5.1 \pm 1.8$ & 0.37 \\
\hline
\end{tabular}

with NTA and for $\mathrm{Pb}$ in those with EDDS. On the other hand, the addition of nutrients had a positive effect on soluble fraction of $\mathrm{Cd}$ and $\mathrm{Pb}$, comparing with control, enhancing the concentration up to 4.02 and $0.71 \%$ of the total content, respectively.

No significant differences were observed regarding the height and plant dry weight between the treatments (results are not shown). Nevertheless, the accumulation of metals in plant leaves was dependent on the plant species, presence or absence of chelate, its type and the concentration used. The $\mathrm{Cd}$ concentration was found to be higher in the used variety of sunflower than that in maize, and both chelates increased significantly the accumulated values when compared to the control (Fig 1).

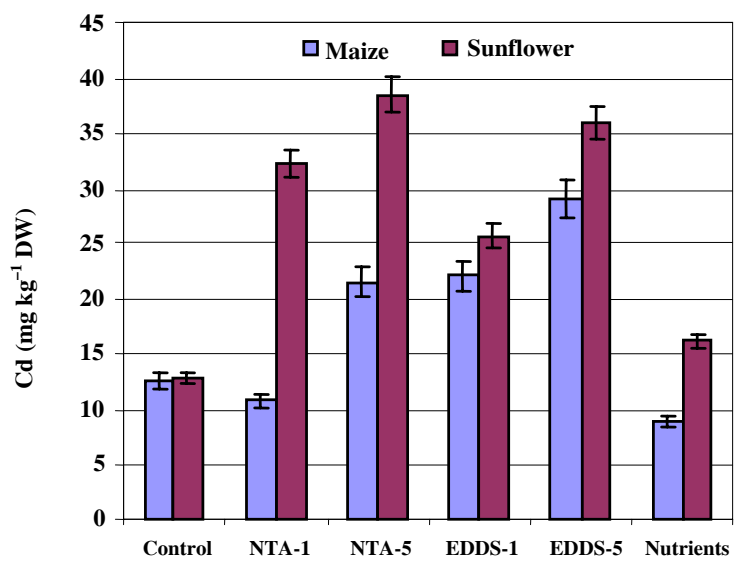

Fig 1. Influence of NTA, EDDS and nutrients on cadmium content in the leaves of maize and sunflower. Bars represent standard errors of the mean $(n=3)$

The highest accumulation was observed in sunflower applying $5 \mathrm{mmol}^{-1}$ concentration of both NTA and EDDS, 38.5 and $36 \mathrm{mg} \mathrm{kg}^{-1}$, respectively, which is approximately three times more than the control. Also, the addition of $1 \mathrm{mmol} \mathrm{l}^{-1}$ EDDS doubled the accumulation of $\mathrm{Cd}$ in the leaves of maize comparing with the same concentration of NTA.

The accumulation of $\mathrm{Pb}$ and $\mathrm{Zn}$ in the leaves and petiole (for petiole, results are not shown) was dependent on the same factors as for $\mathrm{Cd}$ (Table 3 ). The highest concentration of $\mathrm{Pb}\left(66 \mathrm{mg} \mathrm{kg}^{-1}\right)$ was found in sunflower in the treatment with $5 \mathrm{mmol}^{-1}$ EDDS, although the accumulated amounts in the treatment with the same concentration of NTA were similar. In the treatment with nutrients the values were found to be higher than those with chelates in the case of maize, $62 \mathrm{mg} \mathrm{kg}^{-1} \mathrm{~Pb}$.
Regarding the accumulation of $\mathrm{Zn}$ in the leaves of the studied plant species, the enhancement of chelate concentration lead to an increment of the accumulated quantities into the leaves. In this sense the most effective was the addition of $5 \mathrm{mmol}^{-1}$ EDDS in the maize rhizosphere, providing almost fourfold increment of accumulated $\mathrm{Zn}$ in respect to the control.

Table 3. Influence of NTA, EDDS and nutrients on lead and zinc content in the leaves of maize and sunflower. The results are presented as the mean and standard errors $(n=3)$

\begin{tabular}{|c|c|c|c|c|}
\hline \multirow{2}{*}{ Treatments } & \multicolumn{2}{|l|}{$\begin{array}{l}\mathrm{Pb} \\
\left(\mathrm{mg} \mathrm{kg}^{-1}\right)\end{array}$} & \multicolumn{2}{|c|}{$\begin{array}{l}\mathrm{Zn} \\
\left(\mathrm{mg} \mathrm{kg}^{-1}\right)\end{array}$} \\
\hline & Maize & $\begin{array}{l}\begin{array}{l}\text { Sun- } \\
\text { flower }\end{array}\end{array}$ & Maize & $\begin{array}{l}\text { Sun- } \\
\text { flower }\end{array}$ \\
\hline Control & $24.5 \pm 3.6$ & $23 \pm 3.2$ & $130 \pm 21$ & $140 \pm 15$ \\
\hline NTA-1 & $36.2 \pm 4$ & $34 \pm 3.6$ & $246 \pm 31$ & $300 \pm 17$ \\
\hline NTA-5 & $55 \pm 8.1$ & $58 \pm 8.2$ & $388 \pm 29$ & $428 \pm 29$ \\
\hline EDDS-1 & $31 \pm 4.5$ & $39 \pm 4.2$ & $229 \pm 23$ & $286 \pm 24$ \\
\hline EDDS-5 & $47.6 \pm 5$ & $66 \pm 8.5$ & $480 \pm 39$ & $422 \pm 33$ \\
\hline Nutrients & $62 \pm 6$ & $51 \pm 3$ & $342 \pm 32$ & $289 \pm 25$ \\
\hline
\end{tabular}

In this work possible effects of the used biodegradable chelates and nutrients on the soil microorganisms were also studied (Table 4). No significant negative effects on soil bacteria and fungi were observed, although small reduction of the $c f u$ of the fungi in maize rhizosphere was found. In the rhizosphere of both plant species in the treatments with nutrients, the $c f u$ of the studied microorganisms were incremented as result of the microbial degradation and utilization of the amendments as carbon and nitrogen source.

Table 4. Influence of NTA, EDDS and nutrients on $c f u$ of bacteria and fungi in the rhizosphere of maize and sunflower. The results present the mean $(n=3)$

\begin{tabular}{|c|c|c|c|c|}
\hline \multirow{2}{*}{ Treatments } & \multicolumn{2}{|c|}{ Maize } & \multicolumn{2}{|c|}{ Sunflower } \\
\hline & Bacteria & Fungi & Bacteria & Fungi \\
\hline Control & $5 \times 10^{7}$ & $1 \times 10^{4}$ & $4 \times 10^{7}$ & $1.7 \times 10^{4}$ \\
\hline NTA-1 & $4.6 \times 10^{7}$ & $1.6 \times 10^{4}$ & $6.1 \times 10^{7}$ & $10^{4}$ \\
\hline NTA-5 & $3 \times 10^{7}$ & $10^{4}$ & $5 \times 10^{7}$ & $10^{4}$ \\
\hline EDDS-1 & $6 \times 10^{7}$ & $3 \times 10^{4}$ & $3 \times 10^{7}$ & $10^{4}$ \\
\hline EDDS-5 & $3 \times 10^{7}$ & $7 \times 10^{3}$ & $4.5 \times 10^{7}$ & $9 \times 10^{3}$ \\
\hline Nutrients & $2.5 \times 10^{8}$ & $4 \times 10^{4}$ & $4 \times 10^{8}$ & $4.8 \times 10^{4}$ \\
\hline
\end{tabular}




\section{Discussion}

According to the Annual Review of the State of the Environment [25], in Bulgaria 43660 ha of heavy metalcontaminated agricultural lands, which correspond to $0.9 \%$ of all agricultural lands, are registered. Moreover, the contamination is a direct consequence of the industrial and mine activity in polluted regions. Induced phytoextraction has been proposed as an effective approach for extracting heavy metals from soils using plants $[8,5]$. Several chelating agents, such as citric acid, EDTA, DTPA, EDDHA, EDDS, HEDTA and NTA, have been tested for their ability to mobilize and increase the accumulation of heavy metals. In most cases, the EDTA showed better results in solubilizing soil $\mathrm{Pb}$ for root uptake and translocation into the above-ground biomass. In our study the concentration of heavy metals in soil solution changed when introducing chelates and nutrients into the soil. This was in direct correlation with the accumulated metals in the leaves of both plant species. The highest concentration of $\mathrm{Pb}$ was accumulated by sunflower plants treated with $5 \mathrm{mmol}^{-1}$ EDDS, although statistically significant differences, comparing with plants treated with $5 \mathrm{mmol} \mathrm{l}^{-1} \mathrm{NTA}$, had not been found (Table 3). The addition of nutrients resulted in the highest accumulation of $\mathrm{Pb}$ in the leaves of maize, $62 \mathrm{mg} \mathrm{kg}^{-1}$. On the other hand, the $\mathrm{Cd}$ content in the leaves of the sunflower treated with higher concentrations of NTA or EDDS was found as the most effective of all the treatments of our study. The values were almost 3 times higher than the control (Fig 1).

EDDS has an advantage of being readily biodegradable and less toxic to fishes and soil fungi [16]. The calculated half-life of EDDS in soil amended with sludge was $2.5 \mathrm{~d}$ [26]. This means that the residual EDDS in the soil will rapidly be degraded and implies a small risk of leaching of metals to the groundwater.

Since the compounds in the treatment with nutrients possess different biodegradability, the resulted substances (amino and organic acids, chelates and enzymes) are in low, but relatively constant concentrations, leading to lower soil $\mathrm{pH}$ values during a longer period of time. In this sense, the effect of nutrient addition is expected to be better in the case of later harvest [27].

\section{Conclusions}

The total soil metal content in the studied soil was found to be considerably higher than the maximum permissible limits established according to the law. This is clearly reflected in the accumulation of $\mathrm{Cd}, \mathrm{Pb}$ and $\mathrm{Zn}$ in Helianthus annuus L. var. Favorit and Zea mays L. var. Kneja 530. The incorporation into the soil of biodegradable amendments had a positive effect on $\mathrm{CaCl}_{2}$-extractable metals and accumulation in plant leaves. The concentration of extractable metals was found to be the highest for all the metals in the treatments with $5 \mathrm{mmol} \mathrm{l}^{-1}$ of NTA, and for $\mathrm{Pb}$, in those with EDDS, while adding nutrients the soluble fraction of $\mathrm{Cd}$ increased two times compared with the control.
The incorporation of higher concentration of chelates $\left(5 \mathrm{mmol} \mathrm{l}^{-1}\right)$ increased in folds the accumulated values in respect to the control. This was clearly pronounced in both plant species for $\mathrm{Cd}$ and $\mathrm{Zn}$, and in sunflower for $\mathrm{Pb}$.

No negative effects of addition of both chelate concentrations were observed on soil bacteria and fungi. On the other hand, in the treatments with nutrients an increment of the number of $c f u$ of these microorganisms was observed.

\section{Acknowledgements}

The presented results are a part of the research projects 38-04 and 11-05, funded by the Agricultural University - Plovdiv, Bulgaria.

\section{References}

1. NIES, D. H. Microbial heavy-metal resistance. Appl. Microbiol. Biotechnol., 1999, 51, p 730-750.

2. CHO, U. H.; PARK, J. O. Mercury-induced oxidative stress in tomato seedlings. Plant Sci., 2000, 156, p 1-9.

3. VAN ASSCHE, F.; CLIJSTERS, H. Inhibition of photosynthesis in Phaseolus vulgaris by treatment with toxic concentration of $\mathrm{Zn}$ :effect on ribulose-1,5-bisphosphate carboxylase/oxygenase. J. Plant Physiol., 1986, 125, p 355-360.

4. RIVETTA, A.; NEGRINI, N.; COCUCCI, M. Involvement of $\mathrm{Ca}^{2+}$-calmodulin in $\mathrm{Cd}^{2+}$ toxicity during the early phases of radish (Raphanus sativus L.) seed germination. Plant Cell Environ., 1997, 20, p 600-608.

5. HUANG, J. W. and CUNNINGHAM, S. D. Lead phytoextraction: Species variation in lead uptake and translocation. New Phytol., 1996, 134, p 75-84.

6. POSCHENREITER, M.; STOGER, G.; LOMBI, E.; HORAK, O.; WENZEL, W. Phytoextraction of heavy metal-contaminated soils with Thlaspi goesingense and Amaranthus hybridus: Rhizosphere manipulation using EDTA and ammonium sulfate. J. Plant Nutrition and Soil Sceince, 2001, 164, p 615-621.

7. SCHMIDT, U. Enhancing phytoextraction: the effect of chemical soil manipulation on mobility, plant accumulation and leaching of heavy metals. Journal of Environ. Quality, 2003, 32, p 1939-54.

8. BLAYLOCK, M. J.; SALT, D. E.; DUSHENKOV, S.; ZAKHAROVA, O.; GUSSMAN, C.; KAPULNIK, Y.; ENSLEY, B. D.; RASKIN, I. Enhanced accumulation of $\mathrm{Pb}$ in indian mustard by soil-applied chelating agents. Environ. Sci. Technol., 1997, 31, p 860-865.

9. COOPER, E. M.; SIMS, J. T.; CUNNINGHAM, S. D.; HUANG, J. W.; BERTI, W. R. Chelate-assisted phytoextraction of lead from contaminated soils. Journal of Environ. Quality, 1999, 28, p 1709-1719.

10. QUARTACCI, M. F.; ARGILlA, A.; BAKER, J. M.; NAVARI-IZZO, F. Phytoextraction of heavy metals from a multiply-contaminated soil by Indian mustard. Chemosphere, 2006, 63, p 918-925.

11. ALLARD, A.; RENBERG, L.; NEILSON, A. Absence of ${ }^{14} \mathrm{CO}_{2}$ evolution from ${ }^{14} \mathrm{C}$-labelled EDTA and DTPA and the sediment/eater partition ratio. Chemosphere, 1996, 33, p 577-583. 
12. BUCHELI-WITSCHEL, M.; EGLI, T. Environmental fate and microbial degradation of aminopolycarboxylic acids. FEMS Microbiol. Rev., 2001, 25, p 69--106.

13. LUO, C.; SHEN, Y.; LI, X. Enhanced phytoextraction of $\mathrm{Cu}, \mathrm{Pb}, \mathrm{Zn}$ and $\mathrm{Cd}$ with EDTA and EDDS. Chemosphere, 2005, 59, p 1-11.

14. TANDY, S.; SCHULIN, R.; NOWAK, B. The influence of EDDS on the uptake of heavy metals in hydroponical growth of sunflowers. Chemosphere, 2006, 62, p 1454 1463.

15. QUARTACCI, M. F.; IRTELLI, B.; BAKER, A. J. M.; NAVARI-IZZO, F. The use of NTA and EDDS for enhanced phytoextraction of metals from a multiplycontaminated soil by Brassica carinata. Chemosphere, 2007 (in press).

16. GRCMAN, H.; VODNIK, D.; VELIKONJA-BOLTA, S.; LESTAN, D. Ethylenediamine dissuccinate as a new chelate for environmentally safe enhanced lead phytoextraction. Journal of Environ. Quality, 2003, 32, p 500-506.

17. KOS, B.; LESTAN, D. Chelator-induced phytoextraction and in-situ soil washing of Cu. Environ. Pollution, 2004, 132, p 333-339.

18. IRTELLI, B.; NAVARI-IZZO, F. Influence of sodium nitriloacetate (NTA) and citric acid on phenolic and organic acids in Brassica juncea growth in excess of cadmium. Chemosphere, 2006, 65, p 1348-1354.

19. QUARTACCI, M. F.; BAKER, A. J. M.; NAVARIIZZO, F. Nitrilotriacetate and citric acid-assisted phytoextraction of cadmium by Indian mustard (Bassica juncea (L.) Czernj, Brassicaceae). Chemosphere, 2005, 59, p 1249-1255.

20. WU, S. C.; CHEUNG, K. C.; LUO, Y. M.; WONG, M. H. Effects of inoculation of plant growth-promoting rhizobacteria on metal uptake by Brassica jincea. Environ. Pollution, 2006, 140, p 124-135.
21. SHILEV, S.; RUSO, J.; PUIG, A.; BENLLOCH, M.; JORRIN, J.; SANCHO, E. D. Rhizospheric bacteria promote sunflower (Helianthus annuus L.) plant growth and tolerance to heavy metals. Minerva Biotecnologica, 2001, 13, p 37-39.

22. KARSTENSEN, K. H.; RINGSTAD, O.; RUSTAD, I.; KALEVI, K.; JØRGENSEN, K.; NYLUND, K.; ALSBERG, T.; ÓLAFSDÓTTIR, K.; HEIDENSTAM, O.; SOLBERG, H. Methods for chemical analysis of contaminated-sample tests of their reproducibility between Nordic laboratories. Talanta, 1998, 46, p 423-437.

23. MAIZ, I.; ESNAOLA, V.; MILLÁN, E. Evaluation of heavy metal availability in contaminated soils by short sequential extraction procedures. Sci Total Environ, 1997, 206, p 107-115.

24. LOZANO-RODRÍGUEZ, E.; LUGUERA, M.; LUCENA, J. J.; CARPENA-RUIZ, R. O. Evaluation of two different aciddigestion methods in closed systems for trace element determination in plants. Quimica Analitica, 1995, 14, p $27-$ 30.

25. Ministry of Environment and Forests of Bulgaria. Annual review of the state of environment. 2001. Available from Internet: <http://nfp-bg.eionet.eu.int/eea/bg/publicat/ yearbook/2001/landsoil/heavym/pollute.htm>

26. JAWORSKA, J. S.; SCHOWANEK, D.; FEIJTEL, T. C. J. Environmental risk assessment for trisodium [S,S]ethylene diamine disuccinate, a biodegradable chelator used in detergent applications. Chemosphere, 1990, 38, p 3597-3625.

27. SHILEV, S.; NAYDENOV, M. Heavy metal accumulation in maize plants grown at different contamination levels, 1st Scientific Workshop, COST Action 859, "Phytotechnologies to promote sustainable land use and improve food safety", WG 1, 14-16 June 2005, Pisa, Italy. $2005.145 \mathrm{p}$.

\title{
LENGVAI BIODEGRADAVIMĄ PAGERINANČIŲ PATAISYMŲ PRIEMONIŲ POVEIKIS SUNKIŲJŲ METALŲ TIRPUMUI IR AKUMULIACIJAI TECHNINIUOSE PASÉLIUOSE - LAUKO BANDYMAI
}

\author{
S. Shilev, M. Naydenov, N. Tahsin, E. D. Sancho, M. Benlloch, V. Vancheva, K. Sapundjieva, J. Kuzmanova
}

Santrauka

Dirvožemio užterštumas sunkiaisiais metalais yra dažna aplinkos problema visame pasaulyje. Inicijuotas fitoekstrakcijos procesas augaluose gali perkelti i jų antžeminius audinius dideles teršalų koncentracijas. Kadangi kai kurie sunkieji metalai dažniausiai esti netirpios būsenos, reikia pritaikyti chelatų agentus. İ kukurūzus buvo ịterpta rizosfera (var. Kneja 530) ir saulėgrąžos (var. Favorit) EDDS bei NTA 1 ir $5 \mathrm{mmol}^{-1}$ ir $5 \mathrm{~g} \mathrm{~kg}^{-1}$ mineralinių medžiagų, padidinant kadmio, švino ir cinko akumuliuotas koncentracijas. Ekstrahuotos $\mathrm{CaCl}_{2}$ metalo frakcijos padidino chelatų koncentracijos didejjima. Tai pasireiškė visiems metalams, apdorotiems su NTA, ir švinui, paveiktam su EDDS. Visuose eksperimentuose akumuliuoto sunkiojo metalo koncentracijos buvo daug didesnès nei kontroliniame bandinyje. Vadinasi, didesnès NTA ir EDDS koncentracijos atveju akumuliuotas $\mathrm{Cd}$ saulègražos lapuose buvo 3 kartus didesnis. Didžiausia $\mathrm{Pb}$ akumuliacija miežių lapuose išmatuota, pridejjus mineralinių medžiagų $\left(62 \mathrm{mg} \mathrm{kg}^{-1}\right)$. Kita vertus, neigiamas chelatų agentų naudojimo poveikis dirvožemio bakterijoms ir grybeliams augalų derliuje nebuvo nustatytas. Be to, kai buvo pridèta mineralinių medžiagų, padaugejo nagrinejjamų mikroorganizmų.

Reikšminiai žodžiai: sunkieji metalai, fitoekstrakcija, kviečiai, saulègrąžos, EDDS, NTA, lauko bandymai, rizosferos mikroorganizmai.

\section{ПОЛЕВЫЕ ИСПЫТАНИЯ ВЛИЯНИЯ МЕР, СПОСОБСТВУЮЩИХ ДЕГРАДАЦИИ ТЯЖЕЛЫХ МЕТАЛЛОВ, ИХ РАЗЛОЖЕНИЮ И НАКАПЛИВАНИЮ В ТЕХНИЧЕСКИХ ПОСЕВАХ}

\author{
С. Шилев, М. Найденов, Н. Тасин, Е. Д. Санчо, М. Бенллош, В. Ваншева, К. Сапундиева, Й. Кузманова \\ Р е $з$ ю м е
}

Загрязнение почв тяжелыми металлами - наиболее часто отмечаемая проблема во всем мире. Инициированный процесс фитоэкстракции в растениях может способствовать переносу значительных концентраций загрязнителей 
в их поверхностные ткани. В связи с тем, что некоторые тяжелые металлы находятся в нерастворенном состоянии, необходимо применение агентов хелатов. В настоящем исследовании в кукурузу была введена ризосфера (вар. Кnеја 530) и подсолнечник (вар. favorit) EDDS и NTA 1 и 5 ммоль $^{-1}$ ir 5 г кг ${ }^{-1}$ минеральных веществ для увеличения аккумулированных концентраций кадмия, свинца и цинка. Экстрагированные фракции металла $\mathrm{CaCl}_{2}$ способствовали увеличению концентрации хелатов. Это подтверждено исследованием всех металлов, подвергшихся воздействию NTA, и свинца, обработанного с помощью EDDS. Во всех экспериментах концентрации аккумулированного тяжелого металла были значительно больше, чем в контрольном образце. Следовательно, в случае большей концентрации NTA и EDDS содержание аккумулированного в листьях подсолнечника Сd было в три раза больше. Наибольшая аккумуляция $\mathrm{Cd}$ в листьях ячменя зафиксирована в случае добавления минеральных веществ $\left(62\right.$ мг к $\left.{ }^{-1}\right)$. Не было обнаружено и отрицательного воздействия от применения агентов хелатов на бактерии почвы и грибки в урожае растений. Кроме того, в результате добавления минеральных веществ количество исследуемых микроорганизмов увеличилось.

Ключевые слова: тяжелые металлы, фитоэкстракция, ячмень, подсолнечник, NTA, EDDS полевые испытания, микроорганизмы ризосферы.

Dr. Stefan SHILEV is a PhD in Environmental Biotechnology (Microbiology) by the University of Córdoba (Spain) with Directors Prof. Enrique D. Sancho and Prof. Manuel Benlloch. At present he is working as Head Assistant Professor at the Dept of Microbiology and Environmental Biotechnologies in the Agricultural University - Plovdiv, 12, Mendeleev St, 4000-Plovdiv, Bulgaria. E-mail: stefan.shilev@au-plovdiv.bg. He has realized specializations at the Sofia University in 1998, University of Córdoba in 1999-2003, postdoc research stay on proteomics at the University of Córdoba in 2007. He is a participating scientist in COST Action 837 and 859 . He has published 31 abstract for conferences, 23 full papers and 10 monographs. His research interests are in the fields of phyto-, bioremediation, plant - microbe interactions, bacterial proteomics and waste management.

Dr. Mladen NAYDENOV is a PhD in Microbiology. He is Assistant Professor at the Dept of Microbiology and Environmental Biotechnology, Agricultural University - Plovdiv, 12, Mendeleev St, 4000 Plovdiv, Bulgaria. E-mail: mladen@au-plovdiv.bg. He has realized several specializations and published 25 papers and 3 monographs. His research interests are in the fields of biocontrol of plant pests, plant growth-promoting microorganisms, plant - microbe interaction, bioremediation of soil.

Dr. Nurettin TAHSIN is a PhD in Crop Production and an Associate Professor at the Dept of Crop Production in the Agricultural University - Plovdiv, 12, Mendeleev St, 4000-Plovdiv, Bulgaria. E-mail: stefan.shilev@au-plovdiv.bg. He has realized several specializations. He has published 40 full papers and 3 monographs. His research interests are in the fields of phytoremediation, new technologies in sunflower and tobacco cultivation.

Dr. Enrique D. SANCHO is a PhD in Microbiology. He is a Professor at the Dept of Microbiology, Campus of Rabanales, C-6, University of Córdoba, 14071 - Córdoba, Spain. E-mail: edsancho@uco.es. He has realized a number of specializations. He is an expert scientist in COST Action 837 and 859. He has published 76 full papers and 23 monographs. His research interests are in the fields of phytoremediation of arsenic, characterization of bacterial and yeast strains, bacterial proteomics, valorization of by-products.

Dr. Manuel BENLLOCH is a PhD in Plant Physiology. He is a Professor at the Dept of Agronomy, Campus of Rabanales, C-4, 14071 - University of Córdoba, Spain. E-mail: ag1bemam@uco.es. He has realized a number of specializations. $\mathrm{He}$ is an expert scientist in COST Action 837 and 859 and has published 85 full papers and 16 monographs. His research interests are in the fields of phytoremediation of heavy metals, valorization of by-products, transport of solutions in plant.

Dr. Ventsislava VANCHEVA is a PhD in Ecology. She is an Associate Professor at the Dept of Microbiology and Environmental Biotechnologies in the Agricultural University - Plovdiv, 12, Mendeleev St, 4000-Plovdiv, Bulgaria. E-mail: vancheva@au-plovdiv.bg. She has realized several specializations abroad and has published 65 papers and 2 monographs. Her research interests are in the fields of water and soil pollution and waste recycling.

Dr. Krasimira SAPUNDJIEVA is a PhD in Microbiology. She is an Associate Professor at the Dept of Microbiology and Environmental Biotechnologies in the Agricultural University - Plovdiv, 12, Mendeleev St, 4000-Plovdiv, Bulgaria. E-mail: micro@au-plovdiv.bg. She has realized several specializations abroad and has published 45 papers and 4 monographs. Her research interests are in the fields of water and soil pollution and waste recycling.

Dr. Jordanka KUZMANOVA is a PhD in Microbiology. She is a Professor at the Dept of Microbiology and Environmental Biotechnologies and the Rector of the Agricultural University - Plovdiv, 12, Mendeleev St, 4000-Plovdiv, Bulgaria. E-mail: micro@au-plovdiv.bg. She is also the President of the Council of Rectors of Bulgaria. She has realized a number of specializations in Bulgaria and abroad and has published 120 papers and 21 monograph. Her research interests are in the fields of biotechnology, biocontrol and education. 